\title{
PROBLEMS OF TECHNOLOGY FOR THE CONSTRUCTION OF LOW-PROOF HYDROTECHNICAL CONSTRUCTIONS
}

\author{
Nurmatov B.A. \\ Tashkent State Technical University named after Islam Karimov \\ (ToshDTU), Tashkent \\ DOI: 10.31618/ESU.2413-9335.2019.3.60.4-5
}

\section{ANNOTATION.}

This paper discusses the problems of design, construction and operation, the effective use of low-pressure hydraulic structures. The issues of preventing and mitigating emerging problems are given by the installation of modern instruments and equipment, the implementation of repair and rehabilitation works of low-pressure hydraulic structures in operation for management and effective use in the context of water scarcity.

Keywords: low-pressure hydraulic structures, soft soils, basement, reservoir, waterworks, operation, safety, standard, class, water use, water resources, geology.

Today, in our republic there are more than 4.2 million hectares of cultivated land, usually in practice, agricultural products are being harvested by artificial irrigation. About 300 large hydraulic structures are operated for irrigation of these lands, of which 56 are reservoirs with a capacity of 20 billion $\mathrm{m} 3$, about 65 large hydroelectric complexes and about 1,000 small hydraulic structures.

These hydraulic structures were built in the second half of the last century, and their technical condition was weakened due to the fact that they were used for a long time and did not carry out high-quality repairs. Moreover, not taking into account environmental factors during operation leads to a decrease in the reliability of hydraulic structures.

For example, the importance of this issue lies in the fact that, despite notable advances in the use of hydraulic structures, in recent years the number of shutdowns of hydraulic structures has increased, even in emergency situations, as well as in reservoirs, pumping stations and rivers. As a result, every year millions of soums are spent on their recovery.

The main reason for this phenomenon is the lack of safety assessment methods for operating hydropower facilities, which indicates the need to study this problem.

The establishment of safety criteria and risk assessment of accidents of hydraulic structures, as well as the study of defects that lead to complete or partial loss of the facility and the emergence of emergency situations, as well as the study of several options to ensure their sustainability, are a serious engineering problem.

In recent years, in the management and efficient use of water resources, one of the main problems in the context of water scarcity is the implementation of repair and restoration work on low-pressure hydraulic structures in operation, and the prevention of emerging problems through the installation of modern innovative equipment and appliances. In this regard, the Government adopted a number of decrees, orders and government programs to improve the technical condition of deteriorated hydraulic structures, especially low-pressure structures. At the same time, due to the lack of regulatory documents and methods for the design and construction of low-pressure structures in areas where there is a high shortage of water resources, there are a number of problems. For example, from the geological point of view of previously not allowed territories, it is necessary to build new hydraulic structures. Firstly, soft soils are widespread, which do not allow building hydropower facilities in these areas, and secondly, there are no economically sound technological measures to eliminate them.

In accordance with the regulatory documents "Foundations of hydraulic structures" adopted in 1998, when designing the base of hydraulic structures, it should be considered at all stages of building solutions for strength, stability, durability and from an economic point of view of resource saving. For example, in the presence of soft soils on the basis of hydraulic structures, expensive technological methods were used, especially for classes I-II. For buildings of class III-IV, the use of such technological methods is not economically feasible, given the increase in the cost of construction. As can be seen, low-pressure hydraulic structures on soft soils and the methods of their calculation do not meet the requirements of the normative-technical documentation. Low-pressure hydraulic structures built on soft hinges are either in disrepair due to the lack of adequate measures, or their efficiency is reduced.

Despite some progress in the design, construction and operation of large hydraulic structures in the republic and the world, there are still not sufficient grounds for low-pressure hydraulic structures. It is known that low-pressure hydraulic structures erected from concrete and soil are widely used in water resources management (dam, water outlet and spillway), and their advantages: high material resources, labor costs and high cost, as well as long construction periods do not require. Most importantly, they can be built in any climatic, geological and hydrological conditions, regardless of their design.

Hydro technical practice has shown that the design principles of large hydraulic structures are improperly distributed for low-pressure hydraulic structures, which resulted in additional costs for these structures. Therefore, at present, the choice of appropriate technological methods for the design or construction of low-pressure hydraulic structures is a very complex engineering problem. 
Preparation of the foundations of structures is one of the areas in which construction requires the greatest labor and material resources. According to some scientists and experts, the preparation of the foundations of structures is about $10 \%$ of the total cost of construction. In difficult engineering and geological conditions, this figure reaches up to $30 \%$, and for concrete and reinforced concrete structures - up to $23 \%$ of the total construction cost. Working costs are $15-20 \%$.

In the second half of the last century, in order to manage and efficiently use water resources, a number of hydraulic structures of classes III-IV on soft soils were built. Design data of hydraulic structures of III-IV class of the republic were studied and analyzed according to technological methods and methods of calculation for engineering and geological conditions of the built-up area, preparation of bases and ensuring their safety. The results of the analysis showed that in some facilities for preparing the grounds and ensuring their safety, complex and expensive technological methods were used. The author believes that at the same time, material resources and the availability of opportunities were high. At the same time, technological measures aimed at preparing grounds for design and construction and ensuring the safety of hydraulic structures on soft soils can provide optimal and cost-effective ways to ensure safety and increase the stability of the base of lowpressure hydraulic structures on soft soils. Recently, these include technological measures to alleviate the weight of concrete structures, strengthen artificially and fix chemically the base of the structure. However, it is necessary to conduct a series of experiments, field

experiments and shortcomings in existing hydrotechnical objects in order to substantiate their sufficient reliability and applicability for the implementation of such methods in practice.

Research in this direction will allow the development of effective practical measures to ensure and improve the reliability of low-pressure hydraulic structures and prevent possible emergencies.

Conclusion There is still no approved regulatory and technical documentation to ensure safety and improve sustainability, to prepare for the design or construction of low-pressure hydraulic structures. Based on the experience of hydrotechnical construction, methods for calculating the base of low-pressure hydraulic structures do not always meet the requirements of the existing standard. It is required to develop regulatory and technical documentation that takes into account calculation methods and ensure safety, increase stability, design and construction of low-pressure hydraulic structures on soft soils.

Bibliography:

1. Law of the Republic of Uzbekistan "On safety of hydraulic structures".

2. D.T. Paluanov Issues of construction of lowpressure hydraulic structures. Conference proceedings. - Tashkent 2017. - C. 497-500.

3. Paluanov D.T., Nurmatov B.A. "Investigation of the deformation system" Structure-foundation "under the action of static loads" // Bulletin of science and practice scientific journal - T. 4. №4. 2018 г. ISSN 2414-2948

УДК 621.318 .783

МАГНИТНО-ТРАНЗИСТОРНЫЕ ПАРАМЕТРИЧЕСКИЕ СТАБИЛИЗАТОРЫ ПОСТОЯННОГО НАПРЯЖЕНИЯ С ПОВЫШЕННОЙ ЭНЕРГОСБЕРЕГАЮЩЕЙ ХАРАКТЕРИСТИКОЙ.

\author{
Абдуллаев Б., \\ Холбутаева Х.Э., \\ Идрисходжаева М.У. \\ DOI: 10.31618/ESU.2413-9335.2019.3.60.5-8
}

\title{
PARAMETRIC MAGNETIC-TRANSISTOR STABILIZERS OF CONSTANT VOLTAGE WITH ENHANCED ENERGY-SAVING.
}

\author{
Abdullaev B., \\ Kholbutaeva Kh.E., \\ Idriskhodzhaeva M.U.
}

В статье приводится методика повышения магнитно-транзисторных параметрических стабилизаторов постоянного напряжения. Разработаны расчетные и экспериментальные характеристики с учетом принятых допущений. Приведены схемные решения повышения коэффициента полезного действия данного устройства. Нелинейная характеристика магнитного устройства аппроксимирована с учетом его динамических характеристик кривой намагничивания.

In paper the methods of raising of parametric magnitno-transistor stabilizers of constant voltage is considered. Settlement and experimental characteristics taking into account the accepted assumptions are developed. Circuit solutions of raise of efficiency of the given device are resulted. The nonlinear characteristic of the magnetic device is approximated taking into account its dynamic characteristics of a curve of magnetization.

Ключевые слова: транзистор, сердечник, стабилизатор напряжения, преобразователь, источник постоянного тока, индуктивное сопротивление, намагничивание, выходное напряжение, активная нагрузка.

Keywords: transistor, core, voltage stabilizer, converter, DC source, inductive resistance, magnetization, output voltage, resistive load. 